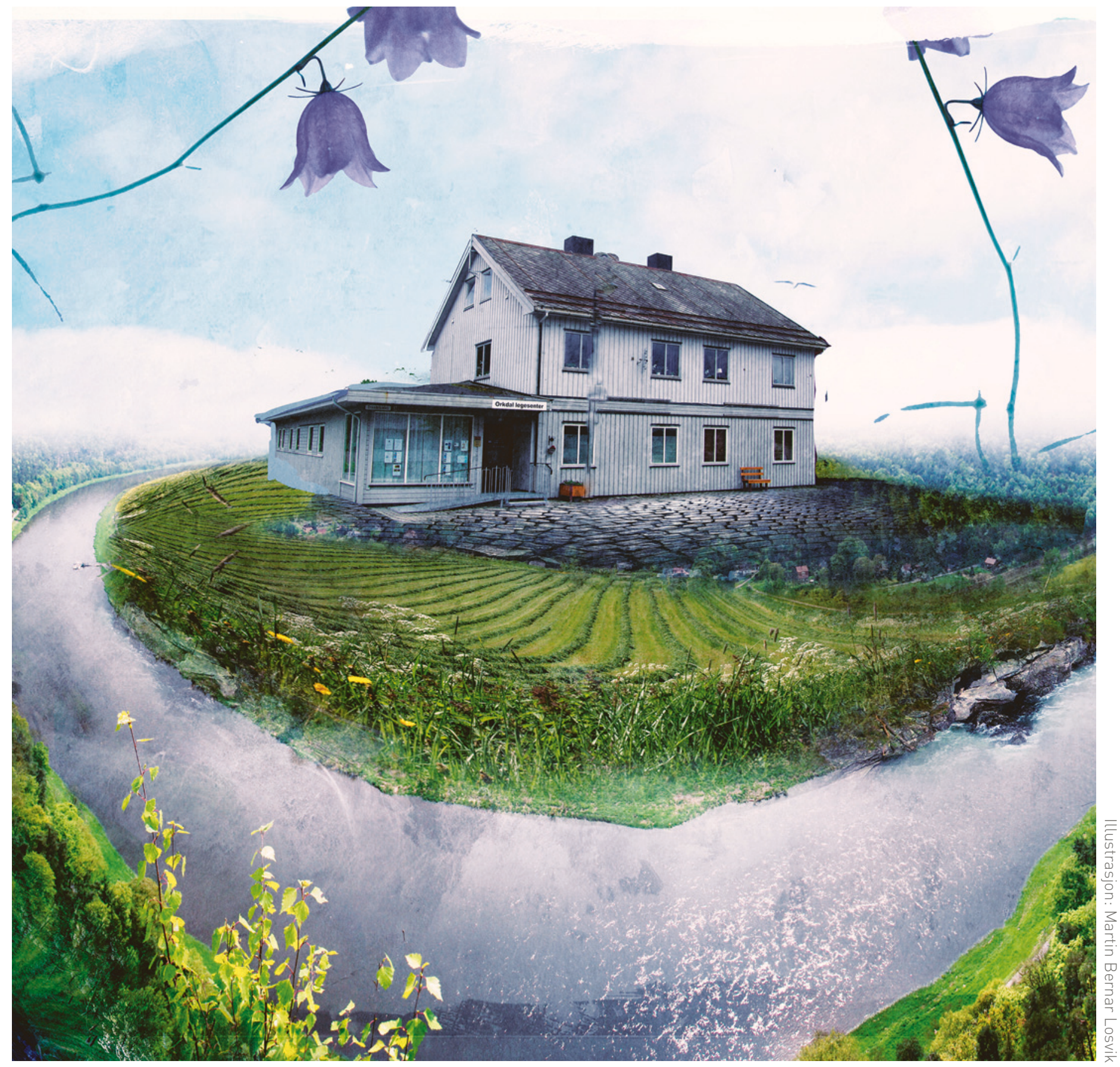

\title{
Orkdal legesenter
}

\footnotetext{
2. Orkdal legesenter befinner seg på Orkanger som er kommunesenteret i Orkdal kommune i Sør-Trøndelag Elven Orkla renner gjennom kommunen og ut i Orkdalsfjorden ved Orkanger. På legesenteret jobber to faste leger, én turnuslege, sykepleier, helsesekretærer og fotterapeut.
} 